\title{
Cardiac functions in children with connective tissue disease
}

\author{
Mai MT Abd El Hady ${ }^{1}$, Mohamed Abd- El Aal Mohamed ${ }^{1}$, Esam M Abou-al Fadl ${ }^{2}$, \\ Ashraf M Abou-Taleb ${ }^{1}$ \\ 1-Pediatrics Department, Faculty of Medicine, Sohag University, Egypt. \\ 2-Rhomatology Department, Faculty of Medicine, Sohag University, Egypt \\ Correspondence should be addressed to Mai MT Abd El Hady; mairody@yahoo.com
}

\begin{abstract}
Background: CTDs, though rare in childhood, are an important cause of morbidity and mortality. Most of them involve multiple organ systems and are associated with presence of auto-antibodies. The main aim of this study to do cardiac functions in children with different types of CTDs. Furthermore, role of myoglobin and other cardiac markers as Troponnin I in early detection of myocardial damage in children with CTDs were studied. Methods: The study included 44 children and adolescent with CTDs come to full up at Pediatrics and Rheumatolorgy Departments during the year 2015. After history taking, careful clinical and cardiac examination; all included children were subjected to echocardiographic examinations and Complete blood count, cardiac markers enzymatic assay.
\end{abstract}

Results: A total of children 44 children and adolescence met the inclusion criteria (22 males and 22 females) with the mean age 11.68 \pm 3.04 years and range from 7-16 years, Mean \pm SD duration of diseases/year were $3.05 \pm 2.61$ years. In this study, 44 cases were diagnosis to had CTDs, $20(45.45 \%)$ cases with idiopathic rheumatoid arthritis, 14 $(31.82 \%)$ cases with SLE and $10(22.73 \%)$ cases with dermatomyositis. The change in cardiac function and cardiac enzymes were not diseases specific or related to the presence of auto-antibodies. But with increase the duration of CTDs and age of patients there were statically significant increase in cardiac function and cardiac enzymes.

Conclusion: CTDs, though rare in childhood, are an important cause of morbidity and mortality. The change in cardiac function and cardiac enzymes were not diseases specific or related to the presence of auto-antibodies. Cardiac function and enzymes were impaired with increase the duration of CTDs and age of the patients

Keywords: Connective tissue diseases, Cardiac functions, Cardiac markers.

\section{Introduction}

Connective tissue diseases (CTDs) are defined as a group of acquired diseases resulting from persistent immune mediated inflammation. In most CTDs there is immune dysregulation resulting in generation of autoreactive $\mathrm{T}$ cells or autoantibodies. $\mathrm{T}$ cells can attack any organ of the body, resulting in a wide array of signs and symptoms (Falcini $\boldsymbol{F}$, 2010). Examples of connective tissue are fat, bone, and cartilage. These disorders often involve the joints, muscles, and skin, but they can also involve other organs and organ systems including the eyes, heart, lungs, kidneys, gastrointestinal tract, and blood vessels (Hochberg M, 1997).

CTDs, though rare in childhood, are an important cause of morbidity and mortality. Most of them involve multiple organ systems and are associated with presence of autoantibodies. Systemic lupus eryethematosus (SLE) is the most common CTDs, the others being Juvenile idiopathic arthritis, Juvenile 
dermatomyositis, systemic sclerosis, mixed connective disease and Sjogren syndrome and others (Moore TL et al., 1999).

The clinical presentation of CTDs in childhood can range from an acute severe illness mimicking a serious infection, to an insidious onset of disease with gradual accumulation of symptoms and signs over weeks to months. Many of the early symptoms can be nonspecific such as unexplained fever, fatigue or loss of appetite (Schlienger RG et al., 2012).

Patients with CTDs have a higher risk of cardiac involvement, which can result in atrio-ventricular dysfunction. Little is known about the chronic influence of CTDs on heart function in children and adolescents. There are many cardiovascular manifestations of CTDs include pericarditis, myocarditis, Libman Sacks endocarditis, cardiomegaly, congestive heart failure (Zulian F, et al., 2007). Left atrio-ventricular diastolic dysfunction has been reported in systemic lupus erythematosus (SLE) (Chung HT et al., 2014, Lio $K$ et al., 2014).

However there is little information about cardiac functions in other CTDs especially in developing countries. Therefore the aim of the work to study cardiac functions in children with different types of CTDs. Furthermore, role of myoglobin and other cardiac markers as Troponnin I, Creatine Kinase (CK-MB) and Lactate Dehydrogenase (LDH) in early detection of myocardial damage in children with CTDs were evaluated.

\section{Patients and methods}

- Place. Sohag University Hospital

- Type of study. prospective case control study
- Number of patients. 44 children with various types of CTDs

- Age from birth up to 16 years old

- Inclusion criteria. All children and adolescent diagnosed with CTDs will be included in the study

- Exclusion criteria. Patients with CTDs and known to have congenital or rheumatic heart diseases, age above 18 years, patients with picture of CTD and not diagnosed yet.

- Children included in this study will be subjected to the following full history \& clinical examination and detailed cardiac examination. Investigation include complete blood count, Creactive protein, Erythrocyte sedimentation rate, serum ferritin, kidney function test, liver function test, rheumatoid factors, Antinuclear antibodies (ANA), anti-doublestranded DNA antibodies (Anti ds DNA), and others specific diagnostic markers of CTDs, Chest X-Ray to assess cardiac size, position, Electrocardiography (ECG) by 12 lead to assess heart rate, rhythm, detect arrhythmia, T-wave changes, prolongation Q-T interval, lengthening of S-T segment and echocardiography: detailed echocardiography study include measuring of ejection fraction $(\%)$ and left ventricular function assessment (left ventricular end diastolic and systolic time interval), pericardium and endocarium valve assessments

- Cardiac markers were done included Troponnin I (it is a protein released when the cardiac muscle damaged, it is specific and sensitive for myocardial damage, Creatine Kinase (CK-MB), Lactate Dehydrogenase (LDH), Myoglobin is a sensitive 
marker for muscle injury, making it a potential marker for heart damage.

- Written informed consent will be obtained from the parents of the children included in the study and approval from local Sohag Faculty of Medicine ethical committee was obtained.

\section{- Statistical analysis}

Data will be analyzed using STATA intercooled version 12.1. Quantitative data will be represented as mean, standard deviation, median and range. Data will be analyzed using student ttest to compare means of two groups and ANOVA and post hoc Bonferroni test for comparison of the means of three groups or more. When the data was not normally distributed KruskalWallis test for comparison of three or more groups and Mann-Whitney test was used to compare two groups. Qualitative data will be presented as number and percentage and compared using either Chi square test or fisher exact test. Graphs were produced by using Excel or STATA program. P value was considered significant if it was less than 0.05 .

\section{Results}

This prospective case control study was carried out at Sohag University Hospitals, during the period from 1/1/2015 to 31/12/2015 at the Department Of Pediatrics, at Sohag University, in collaboration with the Rheumatology Department at Sohag University. A total of children 44 children and adolescence met the inclusion criteria ( 22 males and 22 females) with the mean age 11.68 \pm 3.04 years and range from 7-16 years, Mean \pm SD duration of diseases/year were $3.05 \pm 2.61$ years as shown in Table 1

In this study, 44 cases were diagnosed to have CTDs. Twenty $(45.45 \%)$ cases with idiopathic rheumatoid arthritis (IRA), 14 (31.82\%) cases with SLE and 10 (22.73\%) cases with dermatomyositis. No other CTDs were diagnosed during the study period.

As shown in Table 2, regard complete cardiac examination of studied population, in this study we found that, the mean systolic blood pressure $(\mathrm{mmHg}$ ) was $107.41 \pm 8.30$, while the mean diastolic blood pressure $(\mathrm{mmHg})$ was $65.36 \pm 6.68$, normal chest examination of all studied cases, muffled $1^{\text {st }}$ heart sound in $4(10.9 \%)$ of cases, while accentuated $2^{\text {nd }}$ heart sound in $6(13.9 \%)$, thrill in $4(10.9 \%)$ and murmur in $(18.18 \%)$ of cases.

As shown in Table 3, cardiac function of studied population, the mean \pm SD of ejection fraction was $64.32 \pm 5.93$, the mean \pm SD of shorting fraction was $34.59 \pm 3.71$, the mean \pm SD of left atrial dimension (LA) was $21.18 \pm 2.25$, mean \pm SD of Left ventricular End Systolic dimensions (LVESD) was 34.68 \pm 5.29 , the Mean \pm SD of Left ventricular End Diastolic dimensions (LVEDD) was $38.68 \pm 12.31$, the mean \pm SD of Left ventricular posterior wall dimensions $13.27 \pm 1.62$, the Mean \pm SD of Septal wall thickness(IVS) was $12.95 \pm 1.47$, in this study, there were $4(9.09 \%)$ cases had mild effusion and only one cases had thick pericardium, mitral regurge in $8(18.18 \%)$ patients, tricuspid regurge in 8 $(18.18 \%)$ patients,

As regard cardiac marker of studied population as shown in Table 3, the mean $\pm \mathrm{SD}$ of troponin was $0.07 \pm 0.07(\mathrm{ng} / \mathrm{ml})$, mean $\pm \mathrm{SD}$ of CK-MB was $148.09 \pm 167.66(\mathrm{IU} / \mathrm{L})$, the mean \pm SD of LDH was $260.09 \pm 244.16$ (IU/L), and the mean \pm SD of myoglobin was $61 \pm 27.38(\mathrm{ng} / \mathrm{mL})$.

The comparison between duration of CTDs in years less than 3 years ( $\mathrm{N}=26$ patients), 3-6 years $(\mathrm{N}=14$ patients) and more than 6 years only in $(\mathrm{N}=4$ patients). With increase the durations of CTDs, there were statically significant impairment in echo finding in 
SOHAG MEDICAL JOURNAL

Vol. 21 No.2 July 2017
Cardiac functions in children with connective tissue disease Mai MT Abd El Hady. Et al

Ejection fraction and Shorting fraction, mitral regurg, tricusp regurg ( $\mathrm{P}$ Value $=0.02$, $0.02,0.001$, and 0.001 respectively). Furthermore, with increase the durations of CTDs, there were statically significant increase in cardiac markers as Mean $\pm \mathrm{SD}$ of serum troponin $(\mathrm{ng} / \mathrm{ml})$, Mean \pm SD of serum CK-MB (IU/L), Mean \pm SD of serum LDH and Mean \pm SD of serum myoglobin $(\mathrm{ng} / \mathrm{ml})(\mathrm{P}$ Value $=0.002,0.0006,0.0003$, and 0.0002 respectively).

As shown in Table 4, the comparison between diagnoses of CTDs (IRA 20 patients, SLE 14 patients and dermatomyositis 10 patients) and cardiac function parameters of studied population. According to theses data, there was no one of different CTDs had any statically significant tendency to develop cardiac impartment than others diseases.

Table 1: Characteristics of studied population

\begin{tabular}{|l|l||}
\hline Patients characteristics & Summary statistics \\
\hline \hline Age/year & \\
Mean \pm SD & $11.68 \pm 3.04$ \\
Median (range) & $11.5(7-16)$ \\
\hline \hline Gender & \\
Females & $22(50.00 \%)$ \\
Males & $22(50.00 \%)$ \\
\hline \hline Age of onset/year & \\
Mean \pm SD & $8.45 \pm 3.78$ \\
Median (range) & $8(2-14)$ \\
\hline \hline Duration of diseases/year & \\
Mean \pm SD & $3.05 \pm 2.61$ \\
Median (range) & $2(1-12)$ \\
\hline \hline Weight /kg & \\
Mean \pm SD & $33.73 \pm 7.90$ \\
Median (range) & $34(22-51)$ \\
\hline \hline Length/cm & \\
Mean \pm SD & $137.18 \pm 12.88$ \\
Median (range) & $131.5(120-160)$ \\
\hline \hline BMI & \\
Mean \pm SD & $17.87 \pm 3.01$ \\
Median (range) & $17.84(10.27-23.60)$ \\
\hline \hline Family history & \\
No & $32(72.73 \%)$ \\
Yes & $12(27.27 \%)$ \\
\hline
\end{tabular}


SOHAG MEDICAL JOURNAL

Vol. 21 No.2 July 2017
Cardiac functions in children with connective tissue disease Mai MT Abd El Hady. Et al

Table 2: Cardiac examination of studied population

\begin{tabular}{|l|l||}
\hline Cardiac examination & Summary statistics \\
\hline \hline Chest examination & $44(100 \%)$ \\
\hline Free & \\
\hline Pericardial bulge & $44(100 \%)$ \\
\hline No & \\
\hline Systolic blood pressure (mmHg) & $107.41 \pm 8.30$ \\
Mean \pm SD & $110(90-120)$ \\
Median (range) & \\
\hline Diastolic blood pressure (mmHg) & $65.36 \pm 6.68$ \\
Mean \pm SD & $65(55-75)$ \\
Median (range) & \\
\hline \hline Pulsation & $64.91 \pm 4.19$ \\
Mean \pm SD & $65(60-70)$ \\
Median (range & \\
\hline \hline 1st HS & $40(90.91 \%)$ \\
Normal & $4(9.09 \%)$ \\
Muffled & \\
\hline \hline 2nd HS & $38(86.1 \%)$ \\
Normal & $6(13.9 \%)$ \\
\hline Accentuated & \\
\hline \hline Thrill & $40(89.1 \%)$ \\
No & $4(10.9)$ \\
\hline Systolic thrill & $36(81.82 \%)$ \\
\hline \hline Murmur & $8(18.18 \%)$ \\
No & \\
Yes & \\
\hline
\end{tabular}


SOHAG MEDICAL JOURNAL

Vol. 21 No.2 July 2017
Cardiac functions in children with connective tissue disease Mai MT Abd El Hady. Et al

Table 3: Cardiac function of studied population

\begin{tabular}{|c|c|}
\hline Cardiac function & Summary statistics \\
\hline $\begin{array}{l}\text { Ejection fraction } \\
\text { Mean } \pm \text { SD } \\
\text { Median (range) }\end{array}$ & $\begin{array}{l}64.32 \pm 5.93 \\
65.5(50-75)\end{array}$ \\
\hline $\begin{array}{l}\text { Shorting fraction } \\
\text { Mean } \pm \text { SD } \\
\text { Median (range) }\end{array}$ & $\begin{array}{l}34.59 \pm 3.71 \\
35(24-40)\end{array}$ \\
\hline $\begin{array}{l}\text { Left Atrial dimension (LA) } \\
\text { Mean } \pm \text { SD }\end{array}$ & $21.18 \pm 2.25$ \\
\hline $\begin{array}{llll}\text { Left ventricular } & \text { End } & \text { Systolic } & \text { dimensions } \\
(\text { LVESD) } & & & \\
\text { Mean } \pm \text { SD } & & & \\
\text { Median (range) } & & & \end{array}$ & $\begin{array}{l}34.68 \pm 5.29 \\
37(23-45)\end{array}$ \\
\hline $\begin{array}{l}\text { Left ventricular } \text { End } \\
\text { (LVEDD) }\end{array}$ & $\begin{array}{l}38.68 \pm 12.31 \\
44.5(34.3-52)\end{array}$ \\
\hline $\begin{array}{l}\text { Left ventricular posterior wall dimensions } \\
\text { Mean } \pm \text { SD } \\
\text { Median (range) }\end{array}$ & $\begin{array}{l}13.27 \pm 1.62 \\
13(11-18)\end{array}$ \\
\hline $\begin{array}{l}\text { Septal wall thickness(IVS) } \\
\text { Mean } \pm \text { SD } \\
\text { Median (range) }\end{array}$ & $\begin{array}{l}12.95 \pm 1.47 \\
12.5(10-16)\end{array}$ \\
\hline $\begin{array}{l}\text { Pericardium } \\
\text { Intact } \\
\text { Mild effusion } \\
\text { Thick pericardium }\end{array}$ & $\begin{array}{l}39(88.64 \%) \\
4(9.09 \%) \\
1(2.27 \%)\end{array}$ \\
\hline $\begin{array}{l}\text { Mitrial valve } \\
\text { Normal } \\
\text { Mitral regurge }\end{array}$ & $\begin{array}{l}36(81.82 \%) \\
8(18.18 \%)\end{array}$ \\
\hline $\begin{array}{l}\text { Tricuspid valve } \\
\text { Normal } \\
\text { Tricuspid regurge }\end{array}$ & $\begin{array}{l}36(81.36 \%) \\
8(18.64 \%)\end{array}$ \\
\hline Pulmonary valve (Normal) & $44(100 \%)$ \\
\hline Aortic valve (Normal) & $44(100 \%)$ \\
\hline $\begin{array}{l}\text { Troponin }(\mathbf{n g} / \mathbf{m L}) \\
\text { Mean } \pm \text { SD } \\
\text { Median (range) }\end{array}$ & $\begin{array}{l}0.07 \pm 0.07 \\
0.04(0.01-0.25)\end{array}$ \\
\hline $\begin{array}{l}\text { Creatine Kinase (CK-MB), (IU/L) } \\
\text { Mean } \pm \text { SD } \\
\text { Median (range) }\end{array}$ & $\begin{array}{l}148.09 \pm 167.66 \\
77(30-728)\end{array}$ \\
\hline $\begin{array}{l}\text { Lactate Dehydrogenase LDH (IU/L) } \\
\text { Mean } \pm \text { SD } \\
\text { Median (range) }\end{array}$ & $\begin{array}{l}260.09 \pm 244.16 \\
209.45(70-1323)\end{array}$ \\
\hline $\begin{array}{l}\text { Myoglobin }(\mathbf{n g} / \mathbf{m L}) \\
\text { Mean } \pm \text { SD } \\
\text { Median (range) }\end{array}$ & $\begin{array}{l}61 \pm 27.38 \\
55(23-112)\end{array}$ \\
\hline
\end{tabular}


SOHAG MEDICAL JOURNAL

Vol. 21 No.2 July 2017
Cardiac functions in children with connective tissue disease Mai MT Abd El Hady. Et al

Table 4: Comparison between diagnoses of the disease as regard Cardiac function of studied population

\begin{tabular}{|c|c|c|c|c|}
\hline \multirow[t]{2}{*}{ Cardiac function } & \multicolumn{3}{|c|}{ Diagnosis of the disease } & \multirow[b]{2}{*}{$P$ value } \\
\hline & $\begin{array}{l}\text { IRA } \\
\mathbf{N}=\mathbf{2 0}\end{array}$ & $\begin{array}{l}\text { SLE } \\
N=14\end{array}$ & $\begin{array}{l}\text { Dermatomyositis } \\
\mathrm{N}=10\end{array}$ & \\
\hline $\begin{array}{l}\text { Ejection fraction } \\
\text { Mean } \pm \text { SD } \\
\text { Median (range) }\end{array}$ & $\begin{array}{l}64.8 \pm 4.25 \\
64.5(60-75)\end{array}$ & $\begin{array}{l}64.29 \pm 7.35 \\
67(50-75)\end{array}$ & $\begin{array}{l}63.4 \pm 7.10 \\
66(50-68)\end{array}$ & 0.84 \\
\hline $\begin{array}{l}\text { Shorting fraction } \\
\text { Mean } \pm \mathrm{SD} \\
\text { Median (range) }\end{array}$ & $\begin{array}{l}34.3 \pm 3.44 \\
34(30-40)\end{array}$ & $\begin{array}{l}35.86 \pm 2.18 \\
36(33-38)\end{array}$ & $\begin{array}{l}33.4 \pm 5.48 \\
35(24-38)\end{array}$ & 0.26 \\
\hline $\begin{array}{l}\text { Left Atrial dimension } \\
\text { Mean } \pm \text { SD }\end{array}$ & $20.8 \pm 1.94$ & $22 \pm 2.83$ & $20.8 \pm 1.81$ & 0.26 \\
\hline $\begin{array}{l}\text { LVESD dimensions } \\
\text { Mean } \pm \text { SD } \\
\text { Median (range) }\end{array}$ & $\begin{array}{l}36.7 \pm 4.16 \\
37(29-45)\end{array}$ & $\begin{array}{l}32.86 \pm 6.53 \\
37(23-38)\end{array}$ & $\begin{array}{l}33.2 \pm 4.39 \\
34(27-38)\end{array}$ & 0.07 \\
\hline $\begin{array}{l}\text { LVEDD dimensions } \\
\text { Mean } \pm \text { SD } \\
\text { Median (range) }\end{array}$ & $\begin{array}{l}37.03 \pm 12.84 \\
40(4.3-52)\end{array}$ & $\begin{array}{l}39.53 \pm 14.77 \\
45(4.7-52)\end{array}$ & $\begin{array}{l}40.8 \pm 6.97 \\
44(32-49)\end{array}$ & 0.71 \\
\hline $\begin{array}{l}\text { LV posterior wall } \\
\text { Mean } \pm \text { SD } \\
\text { Median (range) }\end{array}$ & $\begin{array}{l}13.2 \pm 1.28 \\
14(11-15)\end{array}$ & $\begin{array}{l}12.71 \pm 1.33 \\
12(11-15)\end{array}$ & $\begin{array}{l}14.2 \pm 2.25 \\
13(12-18)\end{array}$ & 0.08 \\
\hline $\begin{array}{l}\text { Septal wall thickness } \\
\text { Mean } \pm \text { SD } \\
\text { Median (range) }\end{array}$ & $\begin{array}{l}13 \pm 1.72 \\
12.5(10-16)\end{array}$ & $\begin{array}{l}12.43 \pm 1.22 \\
12(11-15)\end{array}$ & $\begin{array}{l}13.6 \pm 1.07 \\
14(12-15)\end{array}$ & 0.16 \\
\hline $\begin{array}{l}\text { Pericardium } \\
\text { Intact } \\
\text { Mild effusion } \\
\text { Thick pericardium }\end{array}$ & $\begin{array}{l}18(90.00 \%) \\
1(5.00 \%) \\
1(5.00 \%)\end{array}$ & $\begin{array}{l}14(100 \%) \\
0 \\
0\end{array}$ & $\begin{array}{l}7(70.00 \%) \\
3(30.00 \%) \\
0\end{array}$ & 0.08 \\
\hline $\begin{array}{l}\text { Mitral Valve } \\
\text { Normal } \\
\text { Mitral regurge }\end{array}$ & $\begin{array}{l}18(85.00 \%) \\
1(15.00 \%)\end{array}$ & $\begin{array}{l}10(71 \%) \\
2(29.57)\end{array}$ & $\begin{array}{l}4(40.00 \%) \\
5(60.00 \%)\end{array}$ & 0.71 \\
\hline $\begin{array}{l}\text { Tricusped Valve } \\
\text { Normal } \\
\text { Tricuspid regurge }\end{array}$ & $\begin{array}{l}18(85.00 \%) \\
2(15.00 \%)\end{array}$ & $\begin{array}{l}10(71 \%) \\
3(28.57)\end{array}$ & $\begin{array}{l}6(70.00 \%) \\
3(30.00 \%)\end{array}$ & 0.08 \\
\hline $\begin{array}{l}\text { Troponin (ng/ml) } \\
\text { Mean } \pm \text { SD } \\
\text { Median (range) }\end{array}$ & $\begin{array}{l}0.07 \pm 0.08 \\
0.03 \quad(0.01- \\
0.25)\end{array}$ & $\begin{array}{l}0.04 \pm 0.02 \\
0.04 \quad(0.01- \\
0.06)\end{array}$ & $\begin{array}{l}0.03 \pm 0.07 \\
0.08(0.03-0.2)\end{array}$ & 0.16 \\
\hline $\begin{array}{l}\text { CK-MB (u/l) } \\
\text { Mean } \pm \text { SD } \\
\text { Median (range) }\end{array}$ & $\begin{array}{l}132.58 \pm 114.62 \\
91(30-433)\end{array}$ & $\begin{array}{l}65.51 \pm 24.54 \\
54(38.4-107) \\
\end{array}$ & $\begin{array}{l}194.72 \pm 165.81 \\
210(42.6-728)\end{array}$ & 0.08 \\
\hline $\begin{array}{l}\mathbf{L D H} \\
\text { Mean } \pm \text { SD } \\
\text { Median (range) }\end{array}$ & $\begin{array}{l}210.32 \pm 66.83 \\
213.9 \quad(110- \\
317)\end{array}$ & $\begin{array}{l}189.4 \pm 71.72 \\
186.8(70-316)\end{array}$ & $\begin{array}{l}258.58 \pm 349.25 \\
290(160-1323)\end{array}$ & 0.71 \\
\hline $\begin{array}{l}\text { Myoglobin (ng/ml) } \\
\text { Mean } \pm \text { SD } \\
\text { Median (range) }\end{array}$ & $\begin{array}{l}57.77 \pm 27.82 \\
60.5(23-96)\end{array}$ & $\begin{array}{l}50.47 \pm 21.21 \\
45(30-91.3)\end{array}$ & $\begin{array}{l}62.2 \pm 24.5 \\
60(55-112)\end{array}$ & 0.07 \\
\hline
\end{tabular}

NB: LVEDD, Left ventricular End Diastolic dimensions LVESD, dimensions Left ventricular End Systolic dimensions, CK-MB, Creatine Kinase, LDH, Lactate Dehydrogenase, 


\section{Discussion}

Connective tissue diseases (CTDs) are a complex multisystem disease characterized by chronic inflammation, which may involve virtually every organ. Early in the twentieth century, CTDs especially SLE was described as a "generally progressive disease terminating fatally", and the initial report in 1932 of the life expectancy of SLE patients was 3 months to 1 year (peter et al., 2007) .The causes of death were mostly directly associated with periods of active SLE and included renal insufficiency, infection, and sepsis. With improving treatment regimens patients now live longer, with a 10-year survival rate currently reported to be $90 \%$ (Brochers et al., 2004).

As survival in CTDs patients improved, an increased incidence of cardiovascular disease was uncovered, with events occurring even in young Peter et al 2007 reported a bimodal pattern of mortality in SLE, with early deaths from active disease and late death from cardiovascular origin (Peter et al., 2007). Cardiac involvement in CTDs is prevalent in more than $50 \%$ of cases and includes myocarditis, pericarditis, valvular heart disease, coronary arterial disease and conduction abnormalities (Kao, 2002).

Because the symptoms of myocardial involvement in CTDs are usually clinically silent compared with other cardiac involvement, its prevalence in $7 \%$ - $10 \%$ might have been underestimated (Doria et al, 2005). Also autopsy and cardiac magnetic resonance imaging showed a higher prevalence of myocarditis up to $40 \%-70 \%$ (Cacciapouoti et al, 2005).

Standard methods for evaluating cardiac function used in clinical practice often lack the sensitivity to detect myocardial abnormalities in CTDs, cardiac markers as tropinin, CK-BM and myoglobin are a sensitive technique for quantitative assessment of subclinical myocardial dysfunction (Fang et al, 2014).

This study involved 44 children and adolescences ( 22 males and 22 females) with the mean age $11.68 \pm 3.04$ years and range from 7-16 years. Mean $\pm \mathrm{SD}$ duration of CTDs/year was $3.05 \pm 2.61$ years as shown in Table1. Out of them, $20(45.45 \%)$ cases were diagnosed to have idiopathic rheumatoid arthritis (IRA), $14(31.82 \%)$ cases with SLE and $10(22.73 \%)$ was diagnosed cases with dermatomyositis.

In this study we found on cardiomegaly in $8(18.1 \%)$ patients on chest $\mathrm{x}$ ray, and ECG examinations. There has been a growing attention to cardiac function in the field of CTDs. It is well documented that IRA and SLE carries an increased mortality and morbidity from cardiac disease (Maradit-Kremers et al., 2005).

In our study, we classified CTDs patients into 2 groups according to age of the patients $(\leq 10$ years, number 18 patients and more than 10 years old, number 26 patients). In patients with CTDs with age more than 10 years old, there were statically significant differences between the presence of mitral regurge and tricuspid regurge, there were 6 cases in each group compared to no cases in CTDs patient with age less than $10(\mathrm{P}$ Value $=0.01$ and 0.01 respectively). Theses result agree well with the results of Lee et al., 1015 which had described that with increase age and duration of CTDs mitral valve anomalies increased.

Furthermore, with increase in the durations of CTDs, there were 
statistically significant increase in cardiac markers as Mean \pm SD of serum troponin $(\mathrm{ng} / \mathrm{ml})$, Mean $\pm \mathrm{SD}$ of serum CK-MB (IU/L), Mean \pm SD of serum $\mathrm{LDH}$ and Mean \pm SD of serum myoglobin (ng/ml). In a study done by Al-Awadhi et al., 2007 they measured serum concentrations of cardiac troponin-I in patients with IRA, SLE, primary Sjogren's syndrome and Graves' disease and they found that serum troponin-I was elevated with increase in duration of the diseases and seropositively rheumatoid factor.

Comparison between diagnoses of the disease as regard cardiac function of studied population, we do not found any differences between CTDs diagnosis (IRA, SLE, dermatomyositis) and echo findings or cardiac markers parameters and no cases had cardiac markers suggestive of acute myocardial injures (all mean cardiac markers with normal values) and these results agree with $\boldsymbol{A l}$ Awadhi et al., 2007, they studied 50 patients with seropositive rheumatoid factor, five had serum troponin I values greater than $0.1 \mathrm{ng} / \mathrm{ml}$ (the diagnostic value for myocardial infarction). They were admitted to the coronary care unit, where they had serial ECG and serum concentrations of creatinine kinase and its isoenzyme measurements for three days. None of them developed any abnormality suggestive of acute myocardial injures and this agree with our results.

The heart is frequently involved in CTDs. The best known cardiac manifestations are pericarditis and Libman-Saks endocarditis. valvular impairment occurs in advanced stage of the disease. In the present study mitral regurge occured more frequent in 8 $(18.18 \%)$ children and its presence was associated with increased in cardiac markers, as troponin, $\mathrm{CK}-\mathrm{MB}, \mathrm{LDH}$ and myoglobin. These results agree well with Cacciapouoti et al., 2005, they found that functional mitral regurge occur more frequents in SLE patients and associated with elevated troponin I level.

\section{Conclusion:}

CTDs, though rare in childhood, are an important cause of morbidity and mortality. Most of them involve multiple organ systems and are associated with presence of auto-antibodies. A total of children 44 children and adolescence met the inclusion criteria (22 males and 22 females) with the mean age $11.68 \pm 3.04$ years and range from 7-16 years, Mean \pm SD duration of diseases/year were $3.05 \pm 2.61$ years. In this study, 44 cases were diagnosis to had CTDs, $20(45.45 \%)$ cases with idiopathic rheumatoid arthritis (IRA), 14 $(31.82 \%)$ cases with SLE and 10 $(22.73 \%)$ cases with dermatomyositis. The change in cardiac function and cardiac enzymes were not diseases specific or related to the presence of auto-antibodies. But with increase the duration of CTDs and age of patients there were statically significant increase in cardiac function and cardiac enzymes.

\section{Conflict of Interests}

The authors had no conflict of interests.

\section{References}

1. Falcini F (2010): Vascular and connective tissue diseases in the paediatric world. Lupus;13:77-84.

2. Hochberg M (1997): Updating the American College of rheumatology revised criteria for the classification of systemic lupus erythematosus. Arthritis Rheum;40:1725. 
3. Moore TL, Bandlamudi R, Alam SM, Nesher G. (1999): Parvovirus infection mimicking systemic lupus erythematosus in a pediatric population. Semin Arthritis Rheum;28:314-8.

4. Schlienger RG, Bircher AJ and Meier CR (2012): Minocycline-induced lupus: a systematic review. Dermatology;200:223-31.

5. Zulian F, Athreya BH, Laxer R, et al., (2005): Juvenile localized scleroderma: Clinical and epidemiological features in 750 children: an international study. Rheumtaology (Oxford);44:1-7.

6. Chung HT, Huang YL, Yeh KW, et al., (2014): Subclinical deterioration of left ventricular function in patients with juvenile-onset systemic lupus erythematosus. Lupus. Oct 9: 0961203314554249.

7. Lio K, Wang R, Dai M, Lui J, et al., (2014): Evaluation of Left Atrial Function by Real-time 3-D Echocardiography in Patients with Systemic Lupus Erythematosus. J Rheumatol;140;30-4.

8. Brochers AT, Keen Cl, Shoenfeld y, et al (2004): Surviving the butterfly and the wolf, mortality trends in systemic lupus erythematosus. Autoimmun Rev. 3: 423453.

9. Peter EW, Remco K, Luyten, et al., (2007): Premature atherosclerotic cardiovascular disease in systemic lupus erythematosus. 56: 1384-1396.
10. Kao AH (2002): How to manage patients with cardiopulmonary disease? .Best pract Res Clin Rheumatol 16: 211-227

11. Doria A, Iaccarinol G, Sazri -Puttini P, et al., (2005): cardiac involvement in connective tissue diseases. lupus.14:683686.

12. Cacciapouoti F, Galzerano $D$ and Capogrosso P (2005): Impairement of left ventricular function in systemic lupus erythematosus evaluated by measuring myocardial performance index with tissue Doppler echocardiography. Echogradiography. 22: 315-319.

13. Fang $Z Y$, Leano $R$ and Marwick TH (2014): Relationship between longtidunal \& radial contractility in subclinical diabetic heart disease. Clin Sci (Lond). 106: 53-60.

14. Maradit-Kremers $H$, Nicola PJ, Crowson CS, et al., (2005): Cardiovascular death in rheumatoid arthritis: a population-based study. Arthritis Rheum;52(3):722-32.

15. Lee S-W, Park M-C, Park Y-B, and Lee S-K (2015): E/E' ratio is more sensitive than E/A ratio for detection og left ventricular diastolic dysfunction in systemic lupus erythematosus. Lupus;17:195-201.

16. Al-Awadhi AM, Olusi S, Hasan EA, et al., (2007): Serum concentrations of cardiac troponin-I in patients with rheumatoid arthritis, systemic lupus erythematosus, primary Sjogren's syndrome and Graves' disease. Singapore Med J;48(9):847-9. 
SOHAG MEDICAL JOURNAL

Vol. 21 No.2 July 2017
Cardiac functions in children with connective tissue disease Mai MT Abd El Hady. Et al 
SOHAG MEDICAL JOURNAL

Vol. 21 No.2 July 2017
Cardiac functions in children with connective tissue disease Mai MT Abd El Hady. Et al 